* Corresponding author

Phone +421556023236

E-mail address: peter.malega@tuke.sk

(Ing. Peter Malega, PhD.)

Article information

Article history: AMS-Volume16-No.1-00140-12

Received 4 February 2012

Accepted 25 February 2012

\section{Integrated Designing of Production Systems on the Physical and Virtual Modelling Base}

\author{
Jozef Kováč ${ }^{\circ}$, Vladimír Rudy ${ }^{a}$, Albert Mareš ${ }^{b}$, Juraj Kováćc ${ }^{\circ}$ Peter Malega ${ }^{a *}$ \\ a Department of Industial Engineering and Managment, Faculty of Mechanical Engineering, Nemcovej 32, 04200 Košice, Slovak Republic \\ ${ }^{b}$ Department of Technologies and Materials, Faculty of Mechanical Engineering, Mäšiarska 74, 04001 Košice, Slovak Republic \\ 'Department of Production Systems and Robotics, Faculty of Mechanical Engineering, Nemcovej 32, 04200 Košice, Slovak Republic
}

\section{BIOGRAPHICAL NOTES}

Jozef Kováč, prof. Ing. CSc. is professor an also a head of Department of Industrial Engineering and Management. His professional activities are oriented on the analysis and development of new methods and practices of integrated design of manufacturing systems and testing of design solutions.

Vladimír Rudy, doc. Ing. PhD. is associate professor and also a member of Department of Industrial Engineering and Management. His professional area of activity is oriented on the realization of the laboratory system, virtual reality, innovations and CAx systems.

Albert Mareš, Ing. PhD. is assistant professor and also a member of Department of Technologies and Materials. He treats with these activities: virtual reality, CA-technologies and their use in designing and innovation of manufacturing systems, focusing on flexible assembly systems.

Juraj Kováč, Ing. PhD. is assistant professor and also a member of Department of Production Systems and Robotics. He deals with the activities like the realization of the laboratory system, creating of physical and virtual models of production systems, experimental verification of the virtual reality principles.

Peter Malega, Ing. PhD. is assistant professor and also a member of Department of Industrial Engineering and Management. His professional area of activity is oriented on economic effectiveness, competitiveness, productivity and strategic and innovation management.

\section{KEY WORDS}

Integrated designing, innovative designing, variant projects, production systems, production system models, physical modelling, 2D and 3D modelling, virtual modelling, data gloves, head (helmet) display, laboratory designing system, non-automated working cell, virtual reality workplace, multitouch projection table

\section{ABSTRACT}

Integrated designing of production systems on the physical and virtual modelling base is added in specific goal 3: Designing innovation and implementation of production system, high-tech products and development of knowledge intense service for elimination the innovation project risks within formation the research excellence centre in SjF TU of Košice. The solution has to contribute to extension the knowledge in the area of integrated designing of production systems through experimental laboratory activities supported with sophisticated high-tech technologies. 


\section{Introduction}

Within production system designing are important especially these activities: philosophic and conceptual aspects of technological innovation, modelling, existing solutions certified in praxis, financial and material security of innovation changes and multi-purpose and purpose innovation projects. The aim of every project is optimal reduction of designing processes by simultaneous observance of required quality and costs minimisation. Nevertheless it is important to use innovation methods, tools and procedures within solving the various designing problems.

In the present time, innovation methods, practices, tools as well as modern technical and software equipment significantly influence the area of designing of production systems. Contemporary development in this area is affected mainly by progress, which is achieved in modelling of simulation, information, communication and computer technologies. Designing of production system despite the achievement progress requires another integrated development and enhancement about new principles and solutions.

For achievement the goals of research activity will be important to integrate modern technical equipment and software products in laboratory conditions that allow projecting the production process and production systems of various hierarchical levels in physical and virtual reality.

Verification and tested software CAx systems will allow creation of digital models of production system and their simulation verification in virtual reality, which allows to optimize designing processes and to reduce risks of non-optimized proposals.

New algorithmic procedures of production system designing on the base of physical and virtual modelling supported with CAx technologies originate primarily as the consequence of implication of experimental verification of virtual reality technical equipment work.

\section{Innovative Objectives of the Activity}

Trends in solution of innovative problems in the area of designing and implementation of production systems of different levels are aimed at increasing production efficiency, flexibility, reconfiguring, lean and environmental design, and agility as well as eliminating the risks of high-tech manufacturing systems class.
Development of new innovative approaches based on the integrated physical and virtual modelling, simulation and creation of experimental workplaces reduces the risks of production systems projects failure.

Innovative trends in the design of production systems are characterized by a high degree of sophistication, application of integrated high-tech and participation cooperation of users, managers, engineers, technologists, qualified designers and skilled specialists in various fields.

System integration of new methods, procedures, techniques and tools of managerial decision making, designing, planning, organizing, management and operation of manufacturing systems is subjected to the use of modern managerial, designing, and modelling, simulation, information, software, digitization, and other virtual technologies in complex system.

It is important to expand the knowledge and information base for innovative solutions related to market adapting production systems of new generation and training of teaching and preparation centred on design specialists and production managers.

To present designed "adapt to market" production is advantageous mainly in the conceptual stage physical, digital or virtual 3D manufacturing system models (plants) and with the simulation verify their operational function through software products. Interactive, participative, variant designing enables to generate variants and to select the optimal solutions, which can satisfy the requirements of users.

Decision-making activities are implemented through the teamwork of customers, managers, designers and other specialists.

Laboratory support based on the usage of modern technical, software, information and communication resources and knowledge of managers and professional specialists provides high efficiency of project activities and reduces the failure risks of generated projects.

Within the scope of research activity are important the following activities [14]:

- Integrating of current modern design, management, information, digitalization, virtual and other technologies into the complex entity in terms of digital production systems and factories designing needs. 
- Creating of physical reference models of production system projects in terms of hierarchical decomposition (workplaces, cells, production groups, lines, operations, factories) for the basic types of production technologies.

- New technologies verification for the transformation of physical production system models into digital form (e.g. scanning with digital or laser cameras) and their archiving in the database system.

- Generation of 3D digital production system models (projects) in selected CAx systems (e.g. CATIA, DELMIA, etc.).

- Simulation verification of production system operation in virtual reality through technical and software tools of virtual reality (data gloves, multitouch project table, helmet display, etc.).

- Display of design solutions with the tools of virtual reality (animation, or 3D virtual dynamic projection).

-Implementation of production system project type in the project documentation.

\section{Theoretical Support of Innovative Design}

The philosophy of innovative, alternative, interactive and participatory design is based on the assumption that the solution of the production system has three stages:

- It is proposed the initial set of production system variant solutions in line with created goals. It can be used various methods for determining the variants of solution (analytic, morphological, hierarchical generation, usage of reference solutions, etc.). In the case of less complex tasks it can be used the intuitive concepts of generating the variants on the base of the reference type models.

-It is defined acceptable solutions and excluded the inappropriate variants of solution for production system either on the base of the intuitive approach, respectively on the base of usage of logical and mathematical methods.

-It is selected the optimal variant of production system solution as the final stage. There are applied also the decision-making methods, respec-

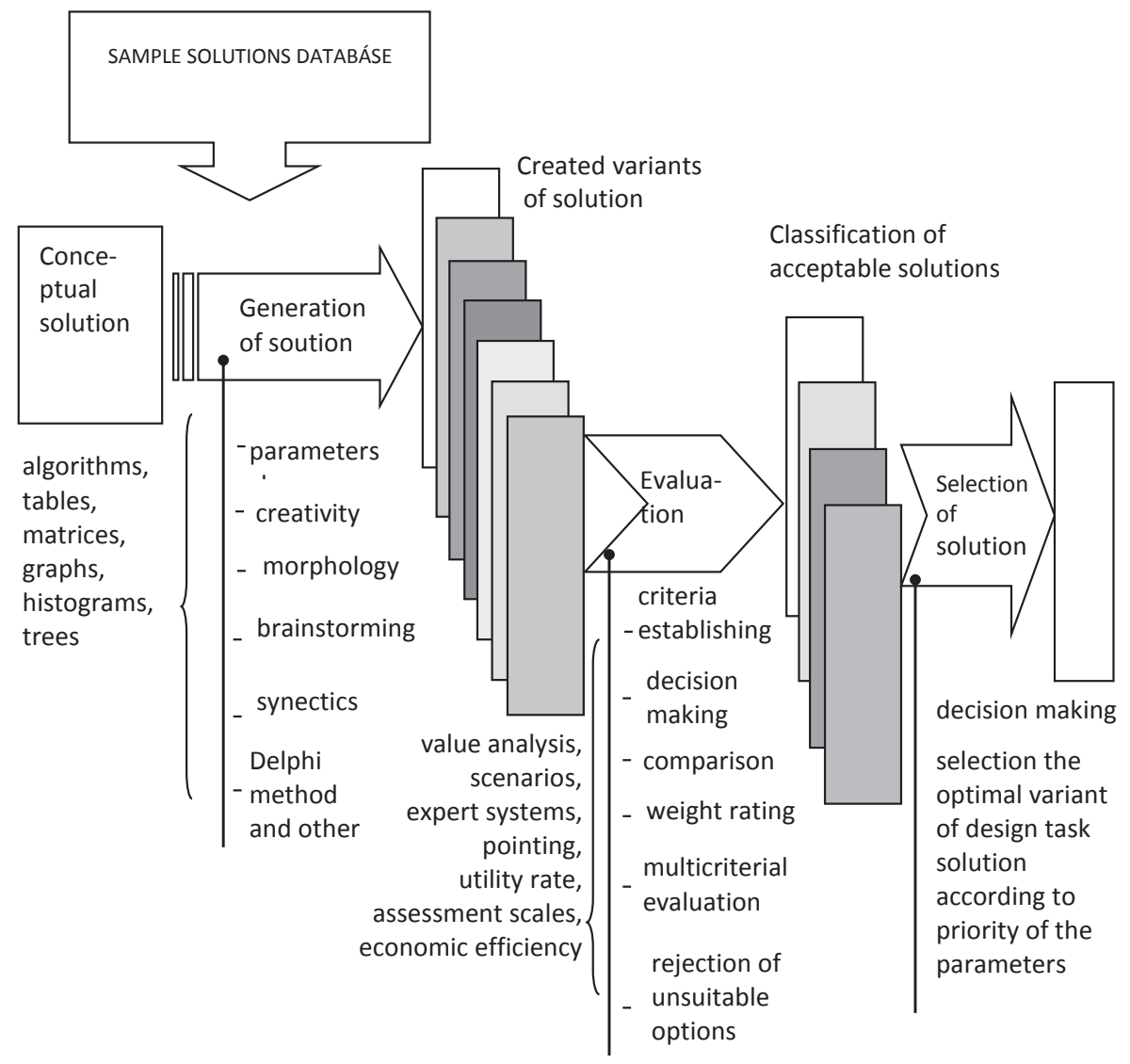

Fig. 1: Illustration of the approach to creating design solutions of manufacturing systems. 
tively optimization criteria. Optimal variant can be obtained on the basis of comparative methods (reference projects), on the basis of simulation activity, etc.

Illustration of the approach to the design of production systems in accordance with this philosophy is shown in Fig. 1.

Innovative design of production systems currently uses modelling in all stages of solution and it is supported with the software products.

The importance of manufacturing system modelling is important for the development of new approaches in designing and optimizing their solutions. Current development trends in the manufacturing companies that lead to quickly "adapt to market" structures require their adaptability to all hierarchical levels of designing and implementation. System-technical development model, which take into account these requirements is shown in Fig. 2.
Used hierarchical decomposition on the individual levels of solution enables optimization of project production structure. This is done in the related detailed activities of the project process. As the basic construction unit are considered autonomous manufacturing modules. From these modules are created production systems of higher rank.

\section{Technical and Software Equipment for Labora- tory Design Support}

In allowed area are realized several kinds of laboratory facilities with appropriate laboratory equipment.

\subsection{Work-cell and line segment}

They are designed for experimental analyses and optimization of working practices, particularly in the assembly, disassembly, balling, packaging and other final manufacturing. The reference solution is the modular hybrid work-cell with technological equipment (Fig. 3) and the section of more-profes

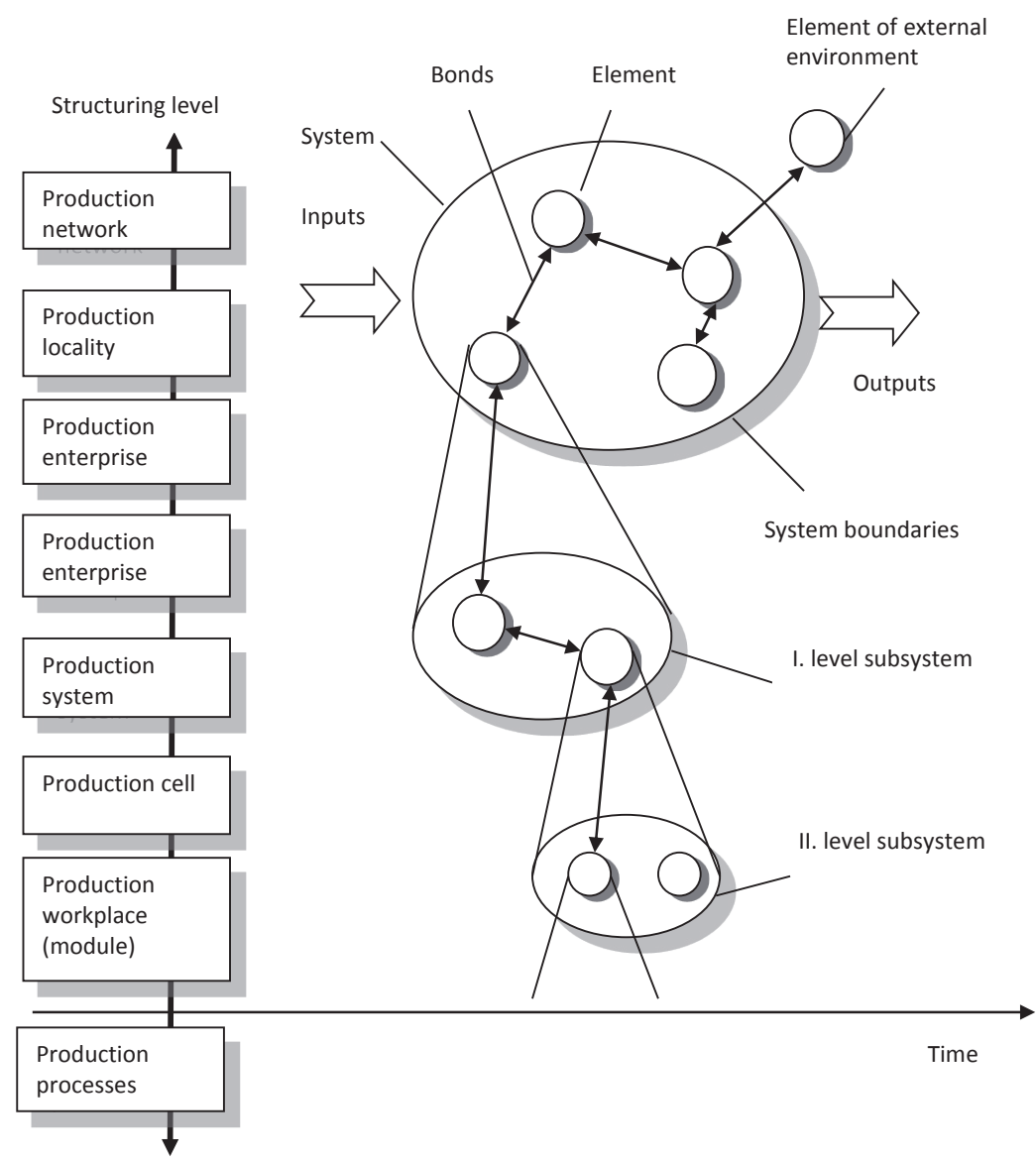

Fig. 2: System-technical model of production systems. 
sion ergonomic modular hybrid line with the transport unit. It also ensures automated workplaces with handling and technological units.

Infrastructure equipment of workplaces consist of energy intakes, racks, panels, trays of sample products and technological equipment (tools, instruments and equipment) and information presentation of production equipment designed solutions, cells and systems, etc.

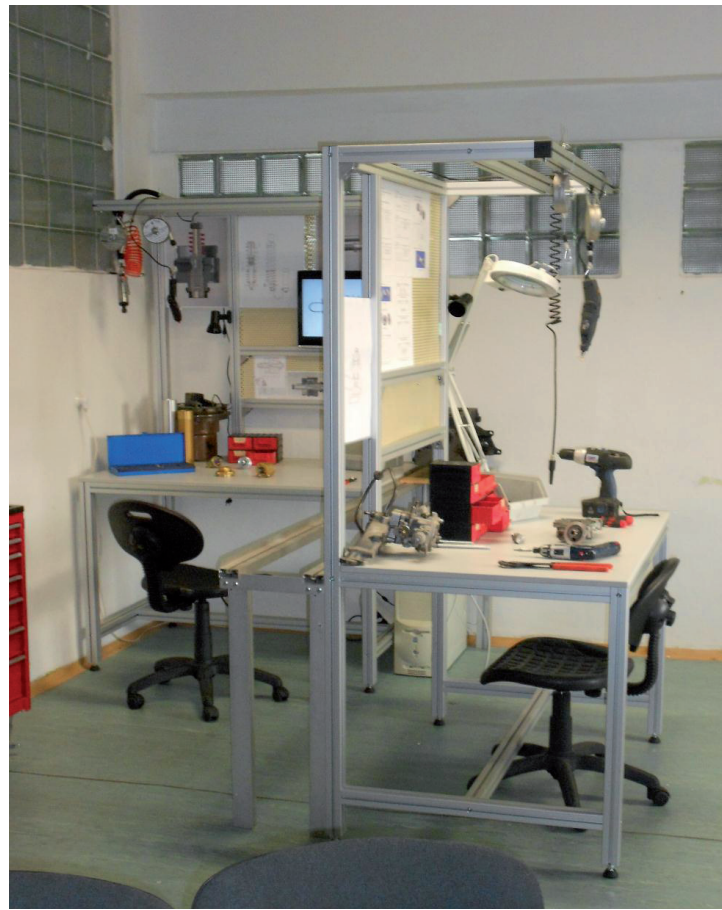

Fig. 3: Hybrid work-cell.

Departments enable to implement these activities:

- Analysis of components, manufacturing technology practices, the implementation of production processes.

- Analysis of raw products, manufacturing facilities, reference production systems.

- Detailed designing of manufacturing operations. Implementation of assembly and disassembly operations.

- Planning of operational activity for the cell respectively for the line.

- Analysis of products, classifiers formation, audit of technologic and economic characteristics.

- Analysis of changes, innovative ideas, opportunities and type strategies.

- Creation of documentation.

\subsection{Integrated laboratory managerial and project sys- tem}

In the structure of integrated project and managerial system are included:

- Horizontal design table (project table - Fig. 4) designed for creating 3D physical models of the production system concepts and plants, including planning and managing their activities. It enables teamwork of different specialists. It uses the $3 D$ models of construction equipment (machines, robots, vehicles, etc.) for generating variants of manufacturing systems in appropriate scales.

- Digital camera system for capturing and digitizing the projected production system (scenes) for the CA technologies treatment.

-2D presentation system. It displays 2D conceptual computer generated scenes on project table.

- PC system with CA technologies for the production of digital and virtual projects at conceptual level and detailed level including their simulation verification (DELMIA software modules for the design of digital factories, respectively another $C A$ system).

- 3D (2D) presentation system for displaying virtual project scenes.

- Virtual technical equipment (data glove, helmet display, 3D projector, etc.) for generating of the production virtual reality, e.g. assembly.

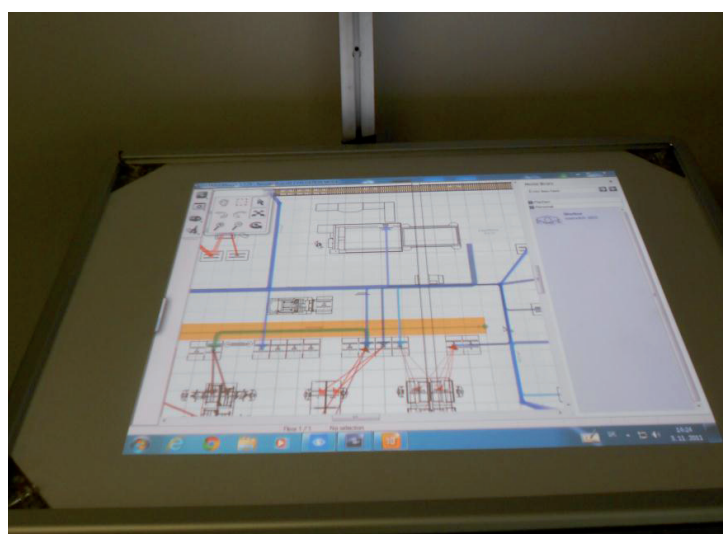

Fig. 3: Project table.

Innovative plans are as follows:

- to integrate the modern technical equipment on the workplace that enable design in physical and virtual reality,

- to verify and testing suitable CAx software products that enable the creation of digital manufacturing system models and their simulation verifica- 
tion including their presentation in virtual reality, - to experimentally verify principles of integrated manufacturing system designing in the physical and virtual reality,

- to experimentally verify the work of the technical equipment in the virtual reality,

- to generate variants of the type solutions of manufacturing systems on the different hierarchical level,

- to optimize designing processes and to reduce the risks of non-optimized production systems proposals.

\subsection{Department of virtual reality}

It consists from modern hardware and software equipment that supports work in virtual reality.

\section{a) Data gloves (yberGlove II (right and left)}

They sense the spatial movement with 18 highprecision measurement sensors. They use patented resistive technology for accurate transformation of hand and finger moves in real-time data.

Wireless glove CyberGlove (Fig. 5) from Immersion Corporation is equipped with 18 sensors that detect movement of the fingers and hand. It uses a precise and sensitive motion sensing technology to fingers and hands in real space and transmits them in to the virtual space. [9]

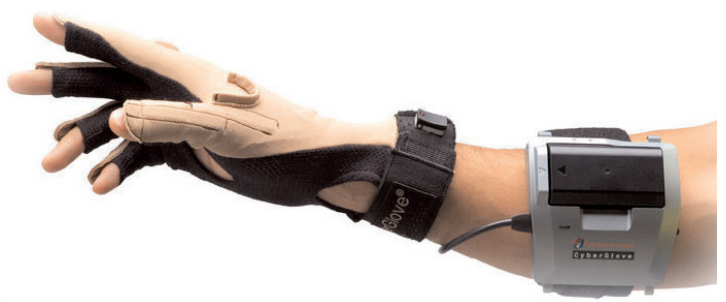

Fig. 5: Cyber Glove II.

The basic system includes a glove, 2 batteries, battery charger and a USB wireless adapter with drivers.

Sensing runs under magnetic method. It uses sensors that are clamped to the glove. They respond to low frequency magnetic field generated by the source. The computer then analyzes the given location and movement in a magnetic field and this motion is transferred into the 3D environment in which the device operates. Sensing of the hand position in space provides "track" facility.

Ascension Flock of Birds is a device that captures and transmits the behaviour of the motion sensor to the computer. Flock consists of the device itself, transmitter and motion sensor, which is mounted on the wrist (Fig. 6). Connection is made via the serial RS-232C port.

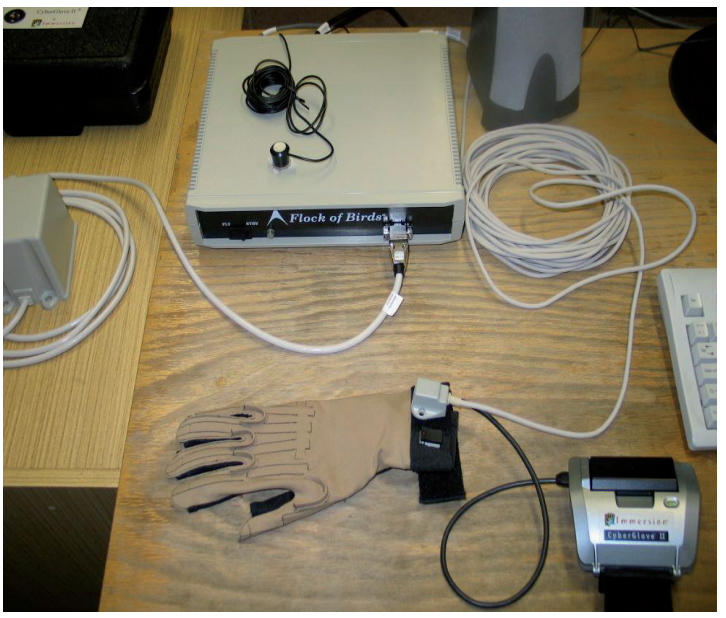

Fig. 6: Data gloves CyberGlove II with track equipment Flock of Birds.

\section{b) Multitouch project table (Fig.7)}

It enables the new form of interaction between the computer and the designer. Multitouch technology combines display technology with sensors that are able to watch more entry points. The technology lets users the interaction with computers naturally.

The device is used for visualization and manipulation of objects in virtual reality. For the implementation and sensing of Multi-Touch points is used the applications CCV (multitouch open-source framework).

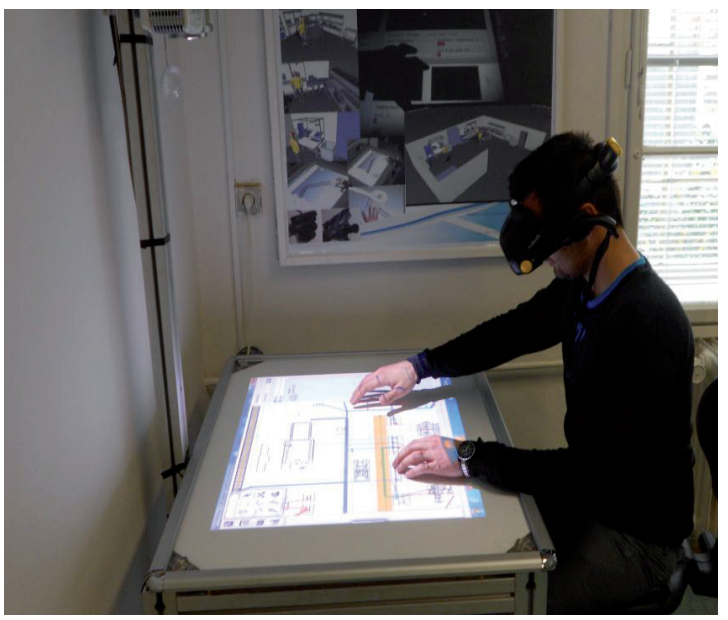

Fig. 7: Multitouch project table. 


\subsection{Computer network}

Computer network with hardware and software for virtual reality modelling is equipped with 2 workstations, 5 - specialized PC (CA), 10 classic PC stations with the accessories, CAD and other specialized software. Software modules of the DELMIA allow virtual 3D productions. Development and validation of manufacturing processes is in the connection to the product in all its developmental stages. Academic license includes the whole portfolio of solutions DELMIA - DELMIA V5, DELMIA Automation, DELMIA Process Engineer, DELMIA QUEST, DELMIA - Human Work Analysis Bundle (HWAB).

DELMIA PLM Express is in the laboratory conditions used primarily for digital plant solution in the small and medium enterprises. Human Work Analysis is used for simulation and ergonomic analysis of the human body in the production environment and the factors that act on it. It includes modules Workplace Simulation (HSU), Human Catalogs (HCU) and Human Work Analysis (HAU).

\subsection{Educational section}

It is the specialized educational space with didactic, computer and training technical arrangement and equipment that are subjected to the training model of education:

- Theoretical training (lectures, training exercises, usage of video-circuit, visualization of the activities from computer presentations, technical documentation, etc.),

- Practical Training (work operation analysis and the optimization of natural samples of components and aggregates, new solutions, etc.),

- Proposals of product design change (innovation variants),

- Design of technology (technological process, jigs, tools)

- Production design and their management, organization, economic evaluation (workstation, line, work-room, factory).

The part from the educational section is shown in Fig. 8.

\section{Presentation of Selected Experimental Work in Laboratory Workstations}

\subsection{Verification and optimization of work by data gloves}

View on the experimental work carried out by the data glove is shown in Fig. 9.

During the realization of work (e.g. assembly,

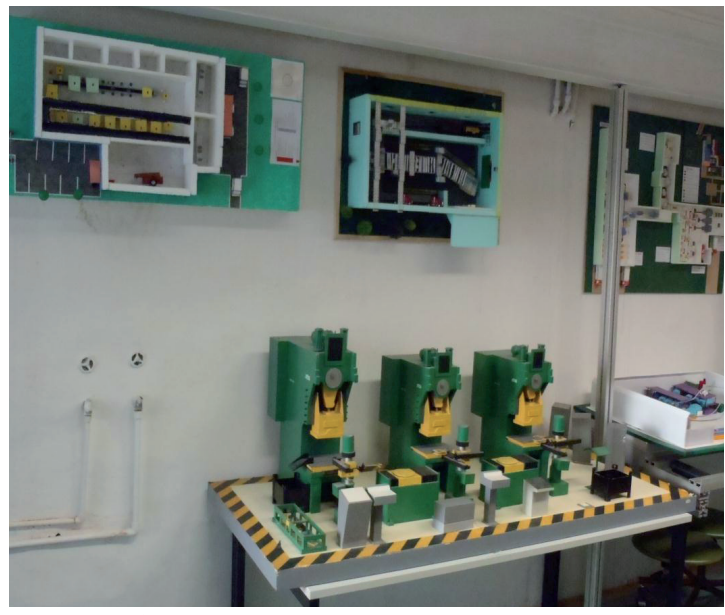

Fig. 8: Part from the educational section.

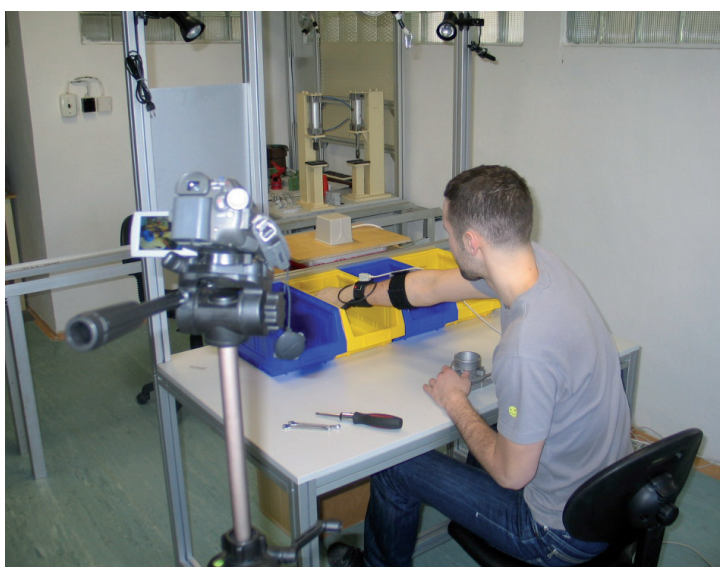

Fig. 9: Physical realization of work by data glove.

disassembly, palletizing, etc.) are sensed the hand movement trajectories with the data glove. Implemented movement is recorded and displayed in virtual reality on a computer terminal screen of workstation. Each trajectory corresponds with the motion of data glove sensor. The glove has 18 sensors and each sensor records its own trajectory and movement is realized forward and back and the result is a dense tangle of lines (Fig. 10).

As the dense tangle of lines is unclear and causes problems in orientation and identification of individual movements, for further analysis is selected the trajectory, that most loyal fit the hand movements made by the work realization. The result of eliminating redundant lines is shown in Fig. 11.

Results of optimization of motional functions are used in further workstation modelling (Fig. 12), optimization and simulation of work in a virtual environment (Fig. 13). 


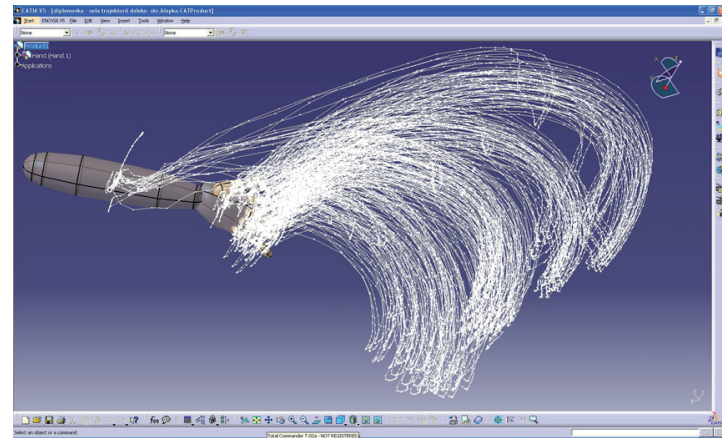

Fig. 10: Motion capture of data glove sensors.

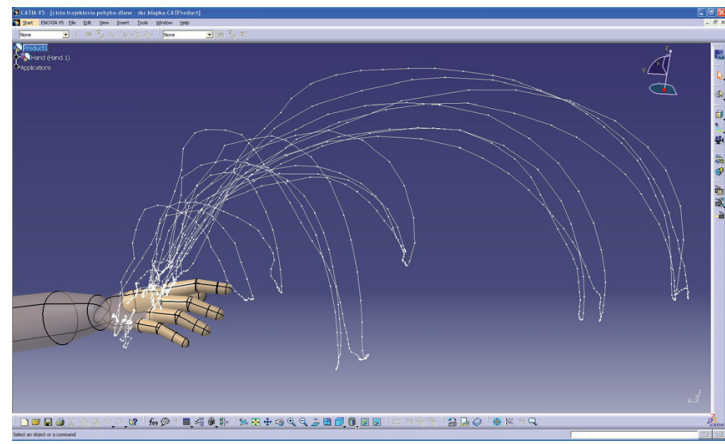

Fig. 11: 3D record of movement after elimination.

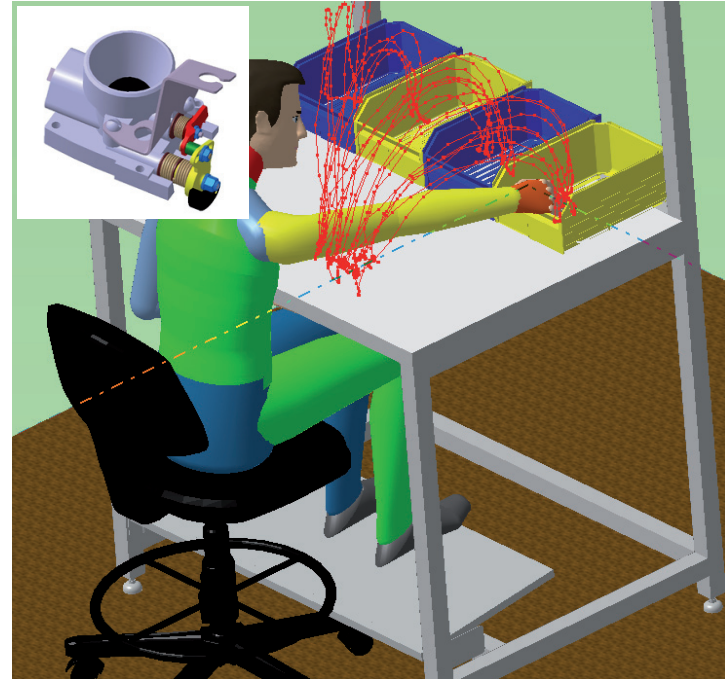

Fig. 12: Model of workplace and movements in product assembly.

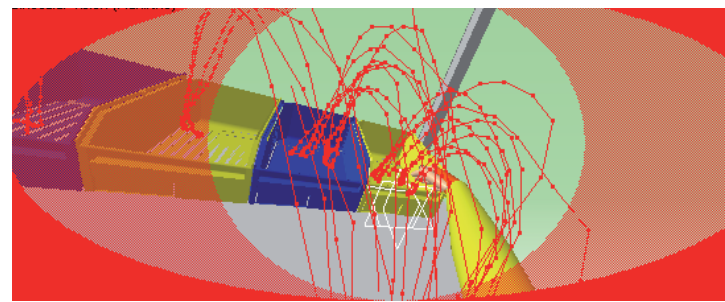

Fig. 13: Employee's field of view by motion.

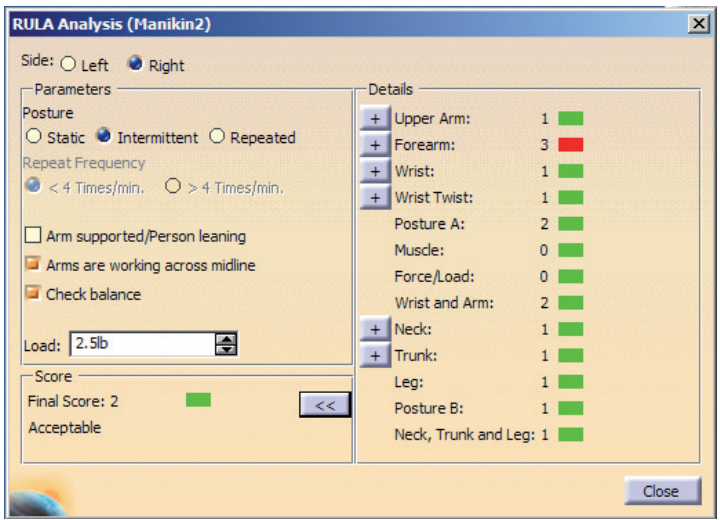

Fig. 14: Results of RULA analysis.

For the valuation of human physical activities in non-automated work activities are used (in CATIA) the function RULA. Parameters setting and analysis results are displayed in the dialog boxes and tables. In the score section of the RULA analysis dialog window are shown partial results, respectively burden assessment of body parts and the resulting evaluation score.

Results of RULA analysis is shown in Fig. 14

The final score can have a value from 1 to 7 and is also expressed in color. The meaning of several values is following:

- 1 and 2 (green) - indicates, that the posture can be accepted under the assumption, that it is not the same for a long time or it is not often repeated for a long time,

- 3 a 4 (yellow) - indicates the need of further detailed research and than, maybe be necessary to change the postures

- 5 a 6 (orange) - indicates, that the research and the changes are necessary in very short time,

- 7 (red) - indicates, that is necessary immediate to research and to change of the postures .

Table 1: Arrangement according to degree of pollution.

\begin{tabular}{|c|c|c|c|c|c|}
\hline $\begin{array}{l}\text { Segment - } \\
\text { part of body }\end{array}$ & Score & 1 & 2 & 3 & 4 \\
\hline Upper arm & from 1 to 6 & & & & \\
\hline Forearm & from 1 to 3 & & & & \\
\hline Wrist & from 1to 4 & & & & \\
\hline Wrist twist & from 1to 2 & & & & \\
\hline Neck & from 1 to 6 & & & & \\
\hline Trunk & from 1 to 6 & & & & \\
\hline
\end{tabular}




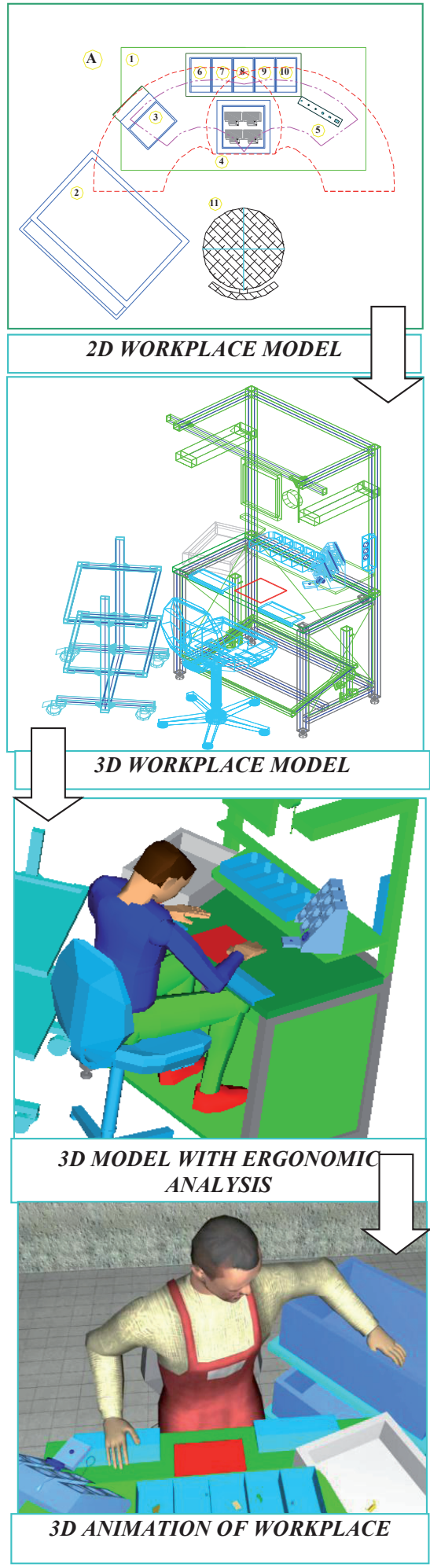

Fig. 15: Visual sequence of procedure by experimental design of non-automatized workplace.
This final score is accounted as a middle value from the partial scores of the particular body parts. For every body part exists a separate evaluating scale, see Table 1. [10]

The visual sequence of the complete procedure by experimental design of workplace is shown in Fig. 15.

\subsection{Development of physical and virtual models of man- ufacturing systems}

Manipulation with virtual models of production instruments through the virtual hand is the relatively new approach in interactive intuitive solutions of allocation problems. The variation of possible solutions in this case is supported by the immediate visual effect that supports decisionmaking activities. Detailed optimized solution is then realized in the CA software product.

Sample of manipulation with virtual model through virtual hand is shown in Fig.16, Fig.17, and Fig.18.

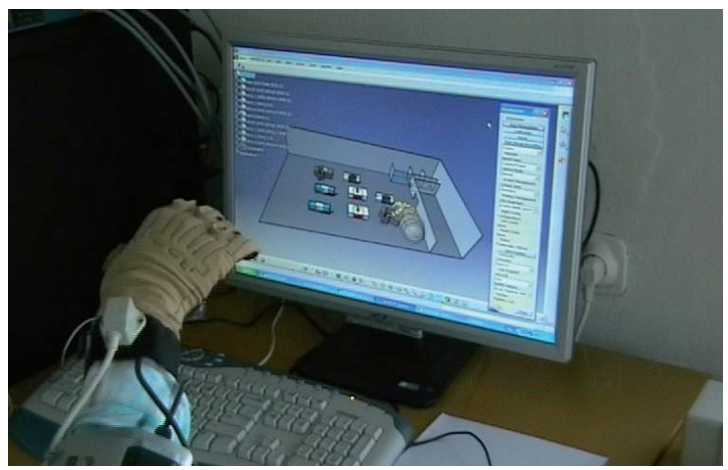

Fig. 16: Transformation of physical movements of data glove into the virtual reality.

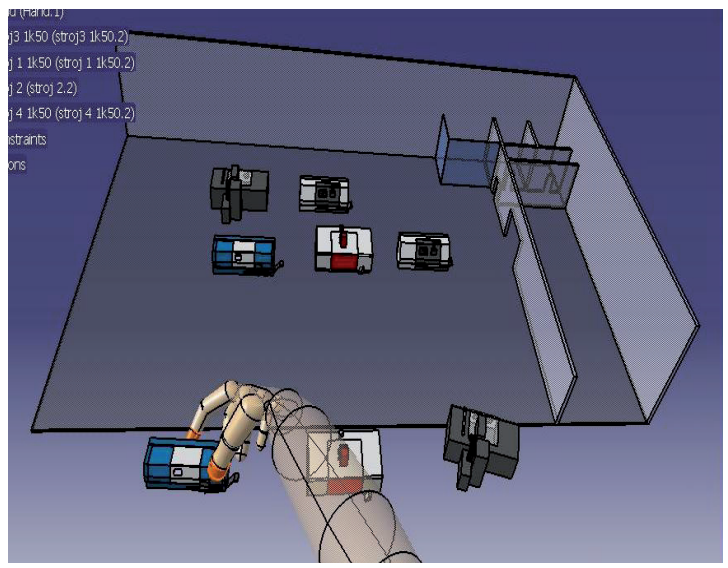

Fig. 17: Grasping of production machine virtual model from the database. 


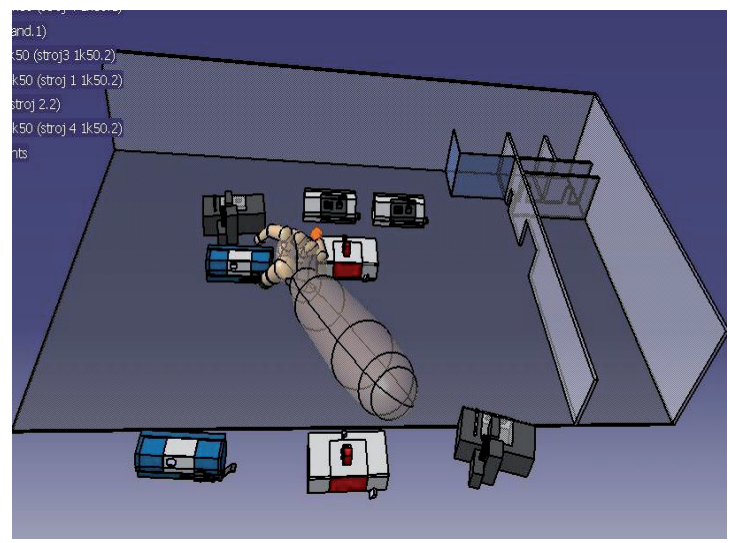

Fig. 18: Placing the virtual model of the machine in the desired position.

In terms of the production system conception and its spatial structure are innovative practices based on the integrated physical and virtual modelling of manufacturing systems particularly effective in the development of production clusters of higher rank. The example of experiment is shown in Fig. 19.

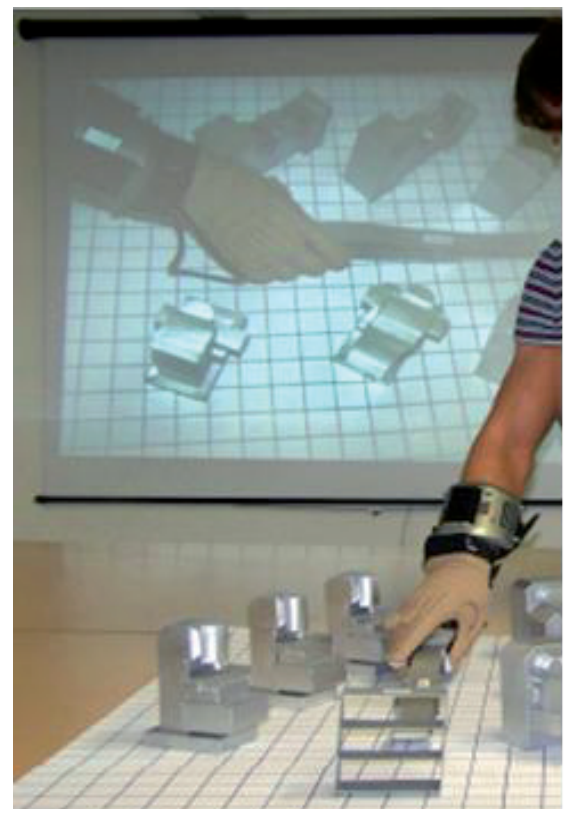

Fig. 19: Example of experiment - application of data glove to solve deployment problems.

\section{Conclusion}

Production system conceptions projected as the new generation systems represent complex integrated solutions created on the basis of exploita- tion modern software, information and communication technologies. Technical and software tools contribute to increasing of productivity, projection activities, quality, products and services value and decreasing of production time.

\section{Acknowledge}

This article was created by implementation of the project "Centre for Management Research technical, environmental and human risks for sustainable development of production and products in engineering"(ITMS: 26220120060) on the grounds of promoting operational research and development program financed by the European Regional Development Fund - Activity 3.1 Integrated Design manufacturing systems based on physical and virtual modelling.

\section{References}

Bracht, U., Geckler, D., Wenzel, S.: Digitale Fabrik - Methoden und Praxisbeispiele. Springer, 2011. ISBN 978-3-540-89038-6

Kováč, J., Knežo, D., Ižaríková, D.: The model of topological relations-relation between two constructed equipment. In: Acta Mechanica Slovaca. Roč. 15, č. 2 (2011), s. 60-68. - ISSN 1335-2393

Kováč, J., Szombathyová, E.: Ergonomics principles of assembly systems projection. In: CO-MAT-TECH 2006. - Bratislava: Vydavatel'stvo STU v Bratislave, 2006 S. 593-597. - ISBN 8022724726

Kováč, M., Kováč, J.: Inovačné projektovanie výrobných procesov a systémov. Košice :TU-SjF, 2011. ISBN 978-80-553-0805-0

Kováč, Jo., Rudy, V., Kováč, Ju.: Tvorba 3D modelov výrobných systémov a zoskupení. In: Transfer inovácií. Č. 11 (2008), s. 261-264. - ISSN 1337-7094 Spôsob prístupu: http://www.sjf. tuke.sk/transferinovacii/

Madarász, L., et al.: Implementation of symbolic modelling in generation of production processes and systems for customer oriented production. In: RAAD 2002. - Budapest : Polytechnic, 2002 P. 391-395. - ISBN 9637154094

Mareš, A., et al.: Viruálna realita - aplikácia dátovej rukavice pri riešení vybraných úloh. In: Úspěch : produktivita a inovace v souvislostech. No. 4 (2010), p. 10-12. - ISSN 1803-5183

Mareš, A., et al.: Analýza pohybu rukou při ruční montáži pomocí datové rukavice. In: IT CAD. Vol. 18, no. 3 (2008), p. 29-31. ISSN 1802-0011

Mareš, A., et al.: Datová rukavice intuitivní nástroj manipulace objekty v CAD. In: IT CAD. Vol. 19, no. 4 (2009), p. 30-31. - ISSN 1802-0011 Spôsob prístupu: http://www.cad.cz.

Mareš, A., Senderská, K.: Virtuálna realita $\vee$ projektovaní montážnych pracovísk. In. Produktivita a inovácie. roč. 8, č. 2/2007, s. 17-18, ISSN 1335-5961 
Ostertagová, E., Kováč, J., Malega, P.: Application of morphological analysis by selection of material flow structure and storage allocation to production system. 1 elektronický optický disk (CD-ROM).In: MMaMS 2011 : Modelling of Mechanical and Mechatronical Systems : proceedings of the 4th international conference : Herlany, Slovakia, 20. - 22. 9. 2011. Košice : Technical University, 2011 S. 374-379. - ISBN 97880-553-0731-2

Rudas, I., J.: CA - system for preparation of production base modernization. In: Proceedings of the jubilee international conference. [Budapešt'] : s.n., 1999 P. 173-176. - ISBN 9637154035

Svoboda, M., Senderská, K., Kováč, J.: Assembled product analysis as a part of assembly systems design procedure. In: Acta Mechanica Slovaca. Roč. 8, č. 1 (2004), s. 91-96. - ISSN 13352393

Kováč, J. a kol.: Integrated Design manufacturing systems based on physical and virtual modelling. In: Centre for Management Research technical, environmental and human risks for sustainable development of production and products in engineering. In: SjF TU Košice, 2011. 